\title{
Deletion mapping on chromosome 10p and definition of a critical region for the second DiGeorge syndrome locus (DGS2)
}

\author{
Simone Schuffenhauer ${ }^{1}$, Peter Lichtner ${ }^{1}$, Popak Peykar-D erakhshandeh ${ }^{1}$, Jan M urken $^{1}$, \\ O skar A H aas ${ }^{2}$, Elke Back ${ }^{3}$, G erhard Wolff ${ }^{3}$, B ernhard Z abel ${ }^{4}$, Ingeborg B arisic ${ }^{5}$, A nita

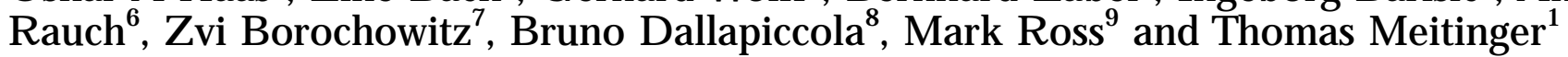 \\ ${ }^{1} A$ bteilung $M$ edizinische $G$ enetik, K inderpoliklinik, $L$ udwig-M aximilians-U niversität $M$ ünchen, $G$ ermany \\ ${ }^{2} \mathrm{CCRI}$, St A nna Kinderspital, Vienna, A ustria \\ 3 Institut für H umangenetik und A nthropologie, Universität Freiburg, G ermany \\ ${ }^{4} \mathrm{~K}$ inderklinik der Universität M ainz, G ermany \\ ${ }^{5}$ Children's H ospital, Zagreb, Croatia \\ ${ }^{6}$ Institut für H umangenetik, U niversität E rlangen-N ürnberg, G ermany \\ ${ }^{7}$ Simon Winter Institute for $\mathrm{H}$ uman G enetics, B nai-Zion M edical Center, Technion-Rappaport Faculti of M edicine, \\ H aifa, Israel \\ ${ }^{8}$ U niversità degli Studi di Roma, 'Tor Vergata', I stituto CSS-M endel, Roma, I taly \\ ${ }^{9}$ Sanger Centre, $\mathrm{H}$ inxton $\mathrm{H}$ all, Cambridge, UK
}

\begin{abstract}
DiGeorge syndrome (DGS) is a developmental field defect, characterised by absent/hypoplastic thymus and parathyroid, and conotruncal heart defects, with haploinsufficiency loci at 22q (DGS1) and 10p (DGS2). We performed fluorescence in situ hybridisations (FISH) and polymerase chain reaction (PCR) analyses in 12 patients with 10p deletions, nine of them with features of DGS, and in a familial translocation $10 p ; 14 q$ associated with midline defects. The critical DGS2 region is defined by two DGS patients, and maps within a $1 \mathrm{cM}$ interval including D10S547 and D10S585. The other seven DGS patients are hemizygous for both loci. The breakpoint of the reciprocal translocation $10 p ; 14 q$ maps at a distance of at least $12 \mathrm{cM}$ distal to the critical DGS2 region. Interstitial and terminal deletions described are in the range of $10-50 \mathrm{cM}$ and enable the tentative mapping of loci for ptosis and hearing loss, features which are not part of the DGS clinical spectrum.
\end{abstract}

Keywords: chromosome 10p; deletion mapping; DiGeorge syndrome; DGS2; ptosis; hearing loss

Correspondence: Simone Schuffenhauer, A bteilung Medizinische $\mathrm{G}$ enetik, $\mathrm{K}$ inderpoliklinik der $\mathrm{U}$ niversität $\mathrm{M}$ ünchen, G oethestr. 29, D -80336 M ünchen, G ermany. Tel: +49 895160 4467; Fax: + 49895160 4780; email: simone@pedgen.med.unimuenchen.de.

R eceived 25 J uly 1997; revised 3 D ecember 1997; accepted 9

D ecember 1997 


\section{Introduction}

D iG eorge syndrome ( $D$ G S, M IM 188400) is considered to be a developmental defect of the third and fourth pharyngeal pouches. It is characterised by an absent or hypoplastic thymus with T-cell deficiency, absent or hypoplastic parathyroid glands with hypoparathyroidism and hypocalcaemia, conotruncal heart defect, craniofacial dysmorphism, and mental retardation. ${ }^{1,2}$ More than $90 \%$ of patients with DGS have a microdeletion of 22q11 (DGS1). . $^{3,4}$ The associated phenotypes are variable, with a large proportion of patients exhibiting only a subset of the above mentioned traits. ${ }^{5}$ The phenotypic spectrum includes the velocardiofacial syndrome (VCFS, MIM 19243), which shows a significant overlap with DGS, specifically hypoparathyroidism, and hypocalcaemia, hypoplastic thymus, T-cell abnormality and cardiac defects. ${ }^{6,7}$ Several candidate genes from the 22q11 deletion region have been cloned, but no genotype-phenotype correlation has emerged so far..$^{8-12}$

The etiology of DGS is heterogeneous and includes teratogens such as alcohol or retinoids ${ }^{1}$ and chromosomal abnormalities, for instance partial monosomies, ${ }^{13-17}$ partial trisomies, ${ }^{18-22}$ and mosaic tetrasomy. ${ }^{23} \mathrm{M}$ ost of these cases represent single reports of DGS associated with a specific chromosomal aberration, with the exception of partial monosomy 10p where ten cases have so far been described. Seven of these patients are hemizygous for the segment 10p13-pter, ${ }^{15,24-29}$ one patient has a monosomy 10 p $11-13,{ }^{30}$ one patient has a monosomy 10p12-p13, ${ }^{31}$ and one patient with an unbalanced de novo translocation 10p;14q was interpreted to be monosomic for 10p14-pter. ${ }^{32}$ The association between partial monosomy 10p and DGS has prompted the definition of a second D G S locus (D GS2) on the short arm of chromosome $10 .^{33}$ Moreover, a patient with partial monosomy 10p has been described, who presents with features of V CFS. ${ }^{31}$ This stresses the variability of the clinical spectrum of the developmental defect associated with partial monosomy 10p, which is similar to that of monosomy 22q11. In addition to the features of the DGS/VCFS spectrum, several other features can be observed in patients with monosomy 10p, including abnormally shaped skull, microcephaly, hand and foot abnormalities, genitourinary anomalies, hearing loss, and severe psychomotoric retardation (for review see). ${ }^{15,34}$

In an effort to localise the genes responsible for the features of the DGS/V CFS spectrum and other abnormalities observed in patients with partial monosomy 10p, we performed deletion analysis in 12 patients with partial monosomy 10p. Nine of these patients showed typical features. The phenotypes of the other three patients were considered not to belong to the DGS/ V CFS spectrum. In addition, we include the analysis of an apparently balanced translocation 10p;14q. This translocation is associated with cleft lip in a male and ventricular septum defect in his son, ${ }^{35}$ features which might be related to $D G S 2$.

Recently, the critical region for DGS2 has been mapped to an interval flanked by the markers D $10 S 1216$ and D $10 S 547 .{ }^{36}$ The deletion map presented here is consistent with this result and further narrows the critical region to a $1 \mathrm{cM}$ interval.

\section{Materials and Methods}

\section{Clinical and Cytogenetic Evaluation}

E pstein-Barr virus-transformed lymphoblast lines ( $L C L$ ) or primary skin fibroblast lines (FCL) were studied from 12 patients (Table 1 ). M etaphase chromosomes from each cell line were karyotyped after GTG banding to confirm monosomy 10p. For one patient with partial monosomy 10p, only slides and DNA samples were available. Information about the sources of the cell lines, their cytogenetically determined deletions, and brief clinical descriptions are presented in Table 1. The phenotypic summaries are based on published reports. More detailed clinical descriptions of five patients, not reported previously, are given below. Cases with GM numbers have been obtained from the National Institute of G enetic M edical Sciences H uman M utant Cell R epository at the Coriell Institute, New Jersey.

Where available, parental DNA was prepared from EDTA anticoagulated peripheral blood or from cell lines according to standard procedures.

\section{DNA Probes}

D NA markers, cosmid, P1 artificial chromosomes (PAC) and yeast artificial chromosomes (YA C) clones used for polymerase chain reactions (PCR) and fluorescence in situ hybridisation (FISH) are listed in Table 2. A II YACs except 815c2 were selected from the Database of the Whitehead Institute (http://www-genome.wi.mit.edu) ${ }^{49}$ and were obtained from the CEPH B-Mega YAC library. The YAC 815c2 was identified from the pooled CEPH B-M ega YAC library as a corresponding to the locus D 10S570 by PCR using published microsatellite primers. ${ }^{37}$ The size of the YAC $747 \mathrm{~h} 7$ was determined by pulsed field electrophoresis as described elsewhere. $^{38}$

PACs corresponding to loci D 10S585, WI-2389 and D 10S1720 were isolated from the library of P. D ej ong (Sanger Center, $\mathrm{H}$ inxton $)^{39}$ by PCR amplification from PAC pools using the primers reported ${ }^{40}$ followed by Southern hybridisation on gridded filters.

\section{FISH studies}

$M$ etaphase spreads were prepared from the cell lines according to standard procedures. FISH was performed with YACS, PACs or cosmids (Table 2) labelled by nick translation with 
biotin-14-dU TP (Sigma) and preannealed with Cot-1 DNA ( $G$ ibco BRL). D etection and visualisation was achieved using the avidin-fluorescein isothiocyanate/antiavidin antibody system described elsewhere. ${ }^{41,42}$ Chromosomes 10 were identified by DAPI counterstaining and in some experiments by simultaneous hybridisation with the nonchimeric YAC 821d2, which maps to $10 \mathrm{q} 23$.

To exclude partial monosomy 22q11, FISH was performed using the cosmid N25 (D 10S75) from the DGS deletion region on 22q11 (O ncor Inc.).

\section{PCR Analysis}

PCR analysis of polymorphic (CA )n repeats was performed to complement the FISH analysis and to determine the parental origin of the deletions. Each (CA)n repeat was amplified from genomic DNA by PCR using published primers. $^{40} \mathrm{PCR}$ reactions consisted of $300 \mathrm{ng}$ of genomic DNA, $150 \mathrm{ng}$ of each of the forward and reverse primers, $0.5 \mathrm{U}$ Taq polymerase and $10 \mu \mathrm{Ci}$ alpha 32PdCTP. Conditions for PCR amplifications were 30 cycles of $94^{\circ} \mathrm{C}$ for $60 \mathrm{~s}$, annealing for $60 \mathrm{~s}$, and $72^{\circ} \mathrm{C}$ for $60 \mathrm{~s}$. The final elongation cycle was $7 \mathrm{~min}$ at $72^{\circ} \mathrm{C}$. The annealing temperature was between $54^{\circ} \mathrm{C}$ and $60^{\circ} \mathrm{C}$ depending on the loci investigated. The amplified products were resolved on $6 \%$ polyacrylamide denaturing gels and detected by autoradiography.

\section{Results}

\section{Clinical analysis}

Clinical data of 12 patients with partial monosomy 10p as well as of a father and son with a reciprocal translocation 10p;14q are presented in Table 1. D ata of the previously reported cases were taken from the literature.

Features of the DGS/V CFS spectrum were observed in nine of the 12 patients, with marked variability of expression. Patients MAJ ${ }^{15}$ and $\mathrm{GM} 6936^{26}$ had all typical traits including T-cell deficiency with recurrent infections, hypoparathyroidism/hypocalcaemia, and tetralogy of Fallot (MAJ) or pulmonary stenosis (GM 6939). ROB showed an aortic valvular stenosis which is not a typical cardiac defect for the D GSN CFS spectrum, whereas patients KAN, TAT, ${ }^{28}, \mathrm{HOV}$ and LEM did not show a cardiac defect, although TAT had a murmur. The latter five patients (ROB, KA N, TAT, HOV, LEM) are affected by frequent infections and/or T-cell abnormality. They were classified as belonging to the DGS/VCFS spectrum due to the combination of hypoparathyroidism and immunodeficiency. Patient MAR had hypocalcaemia and hypoplastic thymus, ${ }^{30}$ whereas MEG had hypoplastic thymus but no hypocalcaemia. ${ }^{31}$ They presented with atrial septum and ventricular defects, respectively, heart defects more frequently observed in VCFS than in D GS. In addition,
MEG has a cleft palate which is also frequent in VCFS.

Phenotype information for the cell line G M 03470 is scanty and the patient is considered not to belong to the DGS/VCFS spectrum, although features of DGS or VCFS cannot be excluded. The diagnosis DGS was ruled out in patients $\mathrm{BIH} \mathrm{H}^{34}$ and $\mathrm{A} M \mathrm{M}$ S (see case report). The bicuspid aortic valve found in BIH is not a typical cardiac defect of the DGS/VCFS spectrum, serum parathyroid hormone and calcium were in the normal range, and despite recurrent infections, the patient showed normal T-cells. A M S has no heart defect and calcium, parathyroid hormone and T-cell levels were also normal. Where data are available, nine out of 10 patients showed postnatal growth retardation and 11/11 patients showed psychomotoric/mental retardation. $O$ ther features present in a significant number of patients with $10 p$ deletions are ptosis (MAR, LEM, MAJ, HOV, ROB, TAT, KAN), abnormality of the kidney and/or urinary tract (MAR, LEM, GM 6936, $B I H, M A J, H O V, K A N)$, crypto-orchidism (MAR, LEM, HOV, ROB, TAT, KAN) and mild anomalies of distal limbs (A MS, MEG, MAR, GM 6936, BIH, MA J, HOV, ROB, TAT). Hernias were observed in MAR, $R O B$ and TAT, hearing loss in BIH, MAJ and HOV, and seizures in G M 6936, HOV, and TA T (Table 1).

Five patients, who have not been previously described, are presented below as case reports.

\section{Case reports}

Patient 1 The female patient AMS is the second child of healthy unrelated parents (mother 29 years old, father 42 years old). She was born in the 41st week of an uncomplicated pregnancy with a weight of $3470 \mathrm{~g}$ (p50-75), a length of $53 \mathrm{~cm}$ (p75-90), a head circumference of $35 \mathrm{~cm}(p 75)$, and A PGAR scores of 10 at 1 and at $5 \mathrm{~min}$. There were no health problems during the first year of life, but psychomotoric development was delayed. She sat at the age of 12 months, walked at 2 years, and spoke only a few simple words at age 4 . Chromosome analysis at age 4 revealed a partial monosomy 10p. Parental karyotypes were normal. Physical examination of the proposita revealed the following features (Figure 1a): brachycephaly, high nasal bridge, anteverted nares, small mouth, high arched palate, apparently low-set ears, clinodactyly 5 on both hands, and bilateral mild cutaneous syndactyly of toes 2 and 3 . Ultrasound of the urinary tract was normal. Length ( $105 \mathrm{~cm}, \mathrm{p} 50-75)$, OFC $(49 \mathrm{~cm}, \mathrm{p} 10)$, and weight $(17 \mathrm{~kg}, \mathrm{p} 50)$ were within the normal range. 
Table 1 Summary of clinical presentations and molecular analysis

\begin{tabular}{|c|c|c|c|c|c|c|}
\hline Patient & G M 3470 & AMS* & $M E G$ & $\mathrm{MAR}^{*}$ & LEM* & G M 6936 \\
\hline $\begin{array}{l}\text { Cell line } \\
\text { R eference }\end{array}$ & \multirow{11}{*}{$\begin{array}{l}\text { FCL } \\
\text { Coriell NG M S } \\
\text { catalogue } \\
\text { del(10)(p12p13) } \\
f\end{array}$} & $\begin{array}{l}\mathrm{LCL} \\
\text { This paper }\end{array}$ & $\begin{array}{l}\mathrm{LCL} \\
{[31]}\end{array}$ & $\begin{array}{l}\mathrm{FCL} \\
{[30]}\end{array}$ & $\begin{array}{l}\text { LCL } \\
\text { This paper }\end{array}$ & $\begin{array}{l}\mathrm{LCL} \\
{[26]}\end{array}$ \\
\hline 10p aberration & & $\operatorname{del}(10)(p 12 p 13)$ & $\operatorname{del}(10)(p 12 p 13)$ & $\operatorname{del}(10)(p 11 p 13)$ & $\operatorname{del}(10)(p 13)$ & $\operatorname{del}(10)(p 13)$ \\
\hline Sex & & & & $\mathrm{m}$ & & \\
\hline $\begin{array}{l}\text { A ge at latest evaluation } \\
\text { (years) }\end{array}$ & & $44 / 12$ & $16 / 12$ & $1 / 12$ & $104 / 12$ & 5 \\
\hline \multicolumn{6}{|l|}{ DGS features } & \\
\hline Hypoparathyroidism & & - & - & & + & + \\
\hline H ypocalcaemia & & - & - & + & + & + \\
\hline H ypoplastic thymus & & - & + & + & - & - \\
\hline T-cell abnormality & & - & + & + & & + \\
\hline R ecurrent infections 1 ) & & - & + & + & UT, OM & UT \\
\hline Cardiac defect 2) & & - & VSD, A SD & A SD & - & PS \\
\hline \multicolumn{7}{|l|}{ O thers } \\
\hline $\begin{array}{l}\text { Prenatal growth } \\
\text { retardation }\end{array}$ & & - & + & - & - & - \\
\hline $\begin{array}{l}\text { Postnatal growth } \\
\text { retardation }\end{array}$ & & - & & + & + & + \\
\hline $\begin{array}{l}\text { Psychomotoric } \\
\text { retardation }\end{array}$ & + & + & + & & + & + \\
\hline M uscular hypotonia & & + & & & + & \\
\hline Seizures & & - & - & & - & + \\
\hline R enal defect 3) & & - & - & $\mathrm{HN}$ & VR & VR \\
\hline Crypto-orchidism & & & & + & + & \\
\hline Hernias & & - & - & $+(1)$ & - & \\
\hline $\begin{array}{l}\mathrm{H} \text { and/foot } \\
\text { abnormalities 4) }\end{array}$ & & $\mathrm{K} 5, \mathrm{CS} 2 / 3$ & $\mathrm{FC}$ & $\mathrm{K} 5, \mathrm{CS} 2 / 3$ & - & K \\
\hline \multicolumn{7}{|l|}{ Craniofacial } \\
\hline A bnormal skull 5) & MC & $B C$ & - & DC & $D C, M C$ & MC \\
\hline Hypertelorism & - & - & - & - & + & + \\
\hline E picanthal folds & & - & + & + & + & + \\
\hline $\begin{array}{l}\text { Downslanting palpebral } \\
\text { fissures }\end{array}$ & & - & - & + & + & - \\
\hline Ptosis & & - & - & $+(r)$ & + & - \\
\hline B road/flat nasal bridge & & -/high & $+/+$ & -/high & $t+t$ & $+/+$ \\
\hline Short nose & & - & + & - & + & \\
\hline A nteverted nares & & - & - & - & + & + \\
\hline Choanal atresia & & - & - & + & - & - \\
\hline Short philtrum & & + & - & + & + & \\
\hline $\mathrm{H}$ igh arched palate & & + & + & l & ? & - \\
\hline Cleft palate or lip & & - & + & - & - & - \\
\hline M icroretrognathia & & - & + & + & + & + \\
\hline Low set malformed ears & & + & $t+t$ & $+/+$ & +- & $+/+$ \\
\hline H earing loss & & - & - & & - & \\
\hline Short neck & & + & - & & - & - \\
\hline DGS/VCFS spectrum & no 7) & no & yes & yes & yes & yes \\
\hline \multirow{2}{*}{\multicolumn{7}{|c|}{$\begin{array}{l}\text { M olecular findings } \\
\text { Parental origin of deletion }\end{array}$}} \\
\hline & & & & & & \\
\hline D eleted loci & $\begin{array}{l}\text { D 10S570- } \\
\text { D 10S586 }\end{array}$ & $\begin{array}{l}\text { D 10S585- } \\
\text { D 10S191 }\end{array}$ & $\begin{array}{l}\text { D 10S585- } \\
\text { D 10S203 }\end{array}$ & $\begin{array}{l}\text { D 10S189- } \\
\text { D 10S595 }\end{array}$ & $\begin{array}{l}\text { pter- } \\
\text { D } 10 S 585\end{array}$ & $\begin{array}{l}\text { pter- } \\
\text { D 10S1216 }\end{array}$ \\
\hline D eletion size (in cM ) 6) & 15 & 10 & 17 & 29 & 30 & 30 \\
\hline
\end{tabular}

A blank space indicates that this feature was not mentioned (is unknown); mat - maternal; pat - paternal; $f$ - female; $m$ - male; available; ${ }^{* *}$ systolic murmur and cardiac enlargement.

1) GT - gastrointestinal tract; OM - otitis media; RT - respiratory tract; UT - urinary tract; 2) A SD - atrial septal defect; AVS defect; 3) DP - dichotomic pyelon; HK - hypoplastic kidney; HN - hydronephrosis; VR - vesicoureteral reflux; 4) CS 2/3 asymmetric skull; BC - brachycephaly; DC - dolichocephaly; MC - microcephaly; 6) The size of terminal deletions is given as the given as the distance between the most distal and the most proximal deleted locus (minimal deletion size); 7 ) patient 3470 was otherwise healthy, his son carries the same translocation and has an isolated V SD. 


\begin{tabular}{|c|c|c|c|c|c|c|}
\hline$\overline{\mathrm{BIH}}$ & $\mathrm{MAJ}^{*}$ & HOV* & ROB* & TAT & $\mathrm{KAN}^{*}$ & G M 10207** \\
\hline $\begin{array}{l}\mathrm{FCL} \\
{[34]}\end{array}$ & $\begin{array}{l}\mathrm{LCL} \\
{[15]}\end{array}$ & $\overline{\text { This paper }}$ & $\begin{array}{l}\text { LCL } \\
\text { This paper }\end{array}$ & $\begin{array}{l}\mathrm{LCL} \\
{[28]}\end{array}$ & $\begin{array}{l}\mathrm{LCL} \\
\text { This paper }\end{array}$ & $\begin{array}{l}\mathrm{LCL} \\
{[35]}\end{array}$ \\
\hline $\begin{array}{l}\operatorname{del}(10)(p 13) \\
m_{4}\end{array}$ & $\begin{array}{l}\text { del(10)(p13) } \\
f \\
28 / 12\end{array}$ & $\begin{array}{l}\operatorname{del}(10)(\mathrm{p} 13) \\
\mathrm{m} \\
410 / 12\end{array}$ & $\begin{array}{l}\text { del }(10)(p 12) \\
m \\
96 / 12\end{array}$ & $\begin{array}{l}\text { del }(10)(p 13) \\
m \\
13 / 12\end{array}$ & $\begin{array}{l}\operatorname{del}(10)(p 13) \\
m \\
3\end{array}$ & $\begin{array}{l}\mathrm{t}(10 ; 14)(\mathrm{p} 13 ; \mathrm{p} 24) \\
\mathrm{m}\end{array}$ \\
\hline $\begin{array}{l}- \\
- \\
- \\
\text { RT, diarrhea } \\
\text { BAV }\end{array}$ & $\begin{array}{l}+ \\
+ \\
+ \\
+ \\
\text { RT, OM } \\
\text { TOF }\end{array}$ & $\begin{array}{l}+ \\
+ \\
- \\
+ \\
\text { UT } \\
-\end{array}$ & $\begin{array}{l}+ \\
- \\
- \\
\text { RT, GT } \\
\text { AVS }\end{array}$ & $\begin{array}{l}- \\
+ \\
- \\
\text { RT } \\
-\end{array}$ & $\begin{array}{l}+ \\
+ \\
- \\
+ \\
\text { RT } \\
-\end{array}$ & $\begin{array}{l}- \\
- \\
- \\
- \\
- \\
\text { (VSD) 8) }\end{array}$ \\
\hline- & - & $?$ & & - & + & - \\
\hline+ & + & + & + & + & + & - \\
\hline+ & + & + & + & + & + & - \\
\hline & + & $\begin{array}{l}+ \\
+\end{array}$ & + & $\begin{array}{l}+ \\
+\end{array}$ & + & $\begin{array}{l}- \\
-\end{array}$ \\
\hline HK (r) & $\mathrm{HK}(\mathrm{r}), \mathrm{DP}(\mathrm{l}), \mathrm{VR}$ & $\begin{array}{l}\text { VR } \\
+\end{array}$ & - & - & $\begin{array}{l}\text { HK (I), VR (I) } \\
+\end{array}$ & $\begin{array}{l}- \\
-\end{array}$ \\
\hline$\overline{\mathrm{K}} 5$ & $\overline{P E}$ & $\overline{\mathrm{K}}$ & $\begin{array}{l}+ \\
\mathrm{K} 5\end{array}$ & $\stackrel{+}{\mathrm{C} S 2 / 3}$ & $\begin{array}{l}- \\
-\end{array}$ & $\begin{array}{l}- \\
-\end{array}$ \\
\hline $\begin{array}{l}\text { MC } \\
+ \\
+\end{array}$ & $\begin{array}{l}+ \\
+ \\
-\end{array}$ & $\begin{array}{l}\text { MC } \\
- \\
+ \\
-\end{array}$ & $\begin{array}{l}- \\
- \\
+ \\
+\end{array}$ & $\begin{array}{l}\text { A S } \\
- \\
+ \\
-\end{array}$ & $\begin{array}{l}\text { A S } \\
+ \\
+ \\
+\end{array}$ & - \\
\hline $\begin{array}{l}- \\
+/+ \\
+ \\
-\end{array}$ & $\begin{array}{l}+(r) \\
+1+ \\
+ \\
+ \\
- \\
+\end{array}$ & $\begin{array}{l}+ \\
+/ \text { high } \\
- \\
+ \\
- \\
-\end{array}$ & $\begin{array}{l}+ \\
+/ \text { high } \\
- \\
+ \\
- \\
-\end{array}$ & $\begin{array}{l}+ \\
+1+ \\
- \\
+ \\
- \\
+\end{array}$ & $\begin{array}{l}+ \\
+/+ \\
+ \\
+ \\
-\end{array}$ & \\
\hline $\begin{array}{l}+ \\
-\end{array}$ & $\begin{array}{l}+ \\
-\end{array}$ & $\begin{array}{l}- \\
-\end{array}$ & - & $\begin{array}{l}+ \\
-\end{array}$ & $\begin{array}{l}+ \\
-\end{array}$ & + \\
\hline $\begin{array}{l}+ \\
+1\end{array}$ & $\begin{array}{l}+ \\
+/+\end{array}$ & $\begin{array}{l}+ \\
+1+\end{array}$ & $\begin{array}{l}+ \\
+\end{array}$ & $\begin{array}{l}+ \\
+/+\end{array}$ & $\begin{array}{l}+ \\
+/+\end{array}$ & \\
\hline+ & + & + & - & & - & - \\
\hline+ & + & + & + & + & + & \\
\hline no & yes & yes & yes & yes & yes & no \\
\hline pter-D $10 S 585$ & $\begin{array}{l}\text { mat } \\
\text { pter-D } 10 S 570\end{array}$ & $\begin{array}{l}\text { pat } \\
\text { pter } \\
\text { D 10S191 }\end{array}$ & $\begin{array}{l}\text { pat } \\
\text { pter- } \\
\text { D 10S548 }\end{array}$ & $\begin{array}{l}\text { pter- } \\
\text { D 10S203 }\end{array}$ & $\begin{array}{l}\text { pat } \\
\text { pter } \\
\text { D 10S203 }\end{array}$ & $\begin{array}{l}\text { breakpoint } \\
\text { interval } \\
\text { D 10S552- } \\
\text { D 10S189 }\end{array}$ \\
\hline 30 & 34 & 38 & 46 & 47 & 47 & - \\
\hline
\end{tabular}

r - right side; I - left side; LCL - lymphoblastoid cell line; FCL - fibroblastoid cell line; *indicates cases where parental DNA waS

aortic valve stenosis; BAV - bicuspid aortic valve; PS - pulmonary stenosis; TO F - tetralogy of Fallot; VSD - ventricular septum cutaneous syndaktyly of toes 2 and 3; FC - finger contractures; KS - klinodaktyly of the fifth finger; PE - pes equinovarus; 5) A S genetic distance between the most distal deleted 10p locus and the most proximal deleted locus. The size of interstitial deletions is defined as "no D GS", due to sparse clinical information, DGS cannot be excluded; 8) G M 10207 has bilateral cleft lip, but is 
H earing and vision appeared normal. L aboratory investigations revealed a normal serum total calcium level ( $2.4 \mathrm{mmol} / \mathrm{l}$, normal range $2.0-2.6 \mathrm{mmol} / \mathrm{l}$ ), and a normal parathyroid hormone level $(69 \mathrm{pg} / \mathrm{ml})$. Immunologic parameters ( $T$-cells, B-cells, immunoglobulins) were also normal.

Patient 2 The male patient LEM is the second child of healthy unrelated parents (mother 25 years old, father 33 years old). He was born at term (38th week) after an uncomplicated pregnancy with a weight of $2800 \mathrm{~g}$ (p10-25), a length of $51 \mathrm{~cm}$ (p50-75), a head circumference of $34 \mathrm{~cm}$ (p50-70), and APGAR scores of $6 / 9 / 10$. Physical examination of the patient at birth revealed crypto-orchidism, small penis, muscular hypotonia, and facial dysmorphisms (Table 1). Laboratory investigations revealed hypocalcaemia (serum total calcium level was $1.6 \mathrm{mmol} / \mathrm{l}$; normal $>2.1 \mathrm{mmol} / \mathrm{l}$ ) and hypoparathyroidism. At 4 months, hypocalcaemia and hypoparathyroidism had persisted, and the proband
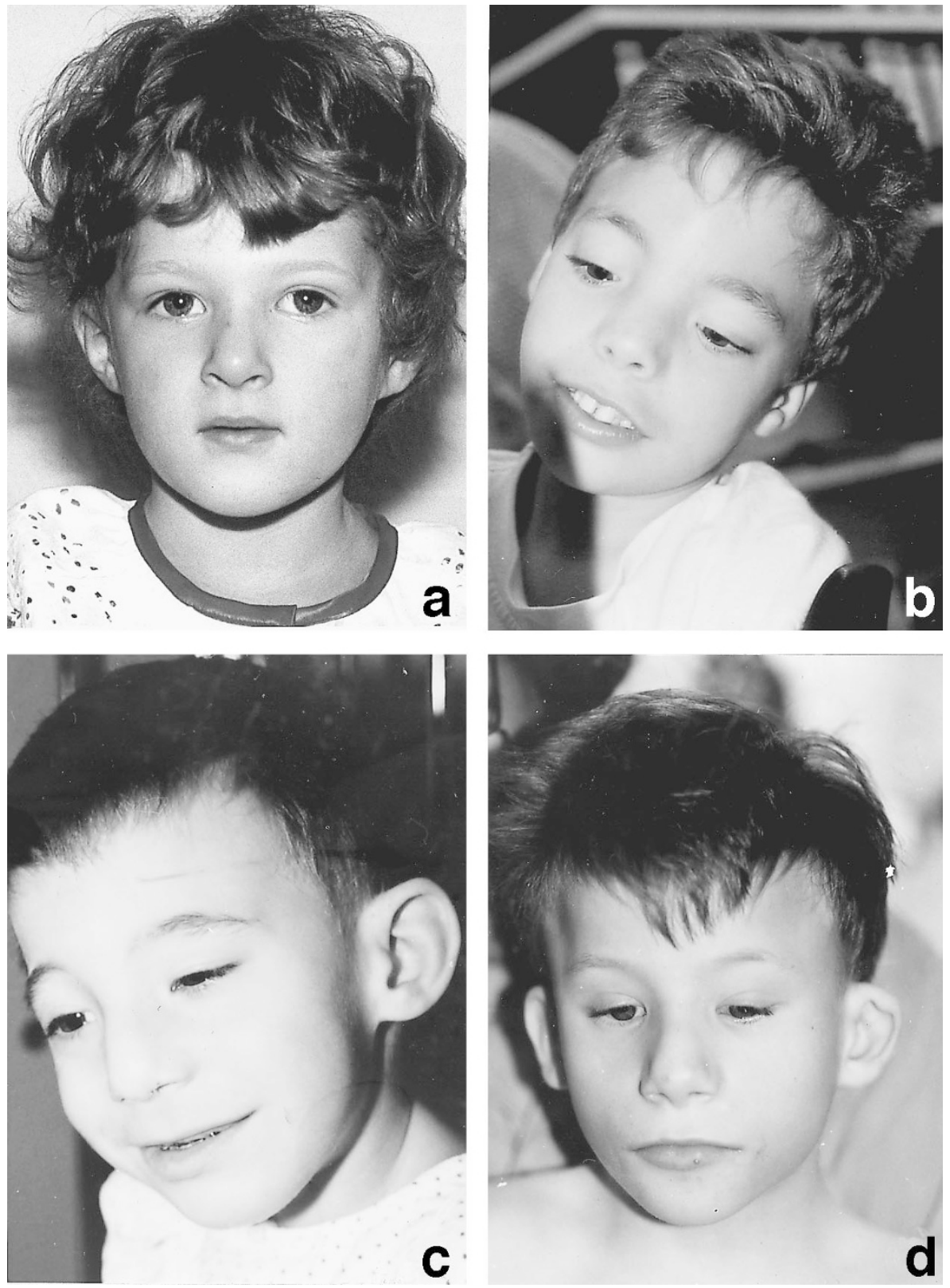

Figure 1 Patients with 10p deletions. (a) patient AM S at age 4 4/12 years, (b) patient LEM at age 10 4/12 years, (c) patient H OV at age 4 10/12 years, and (d) patient ROB at age 9 6/12 years 
was treated with calcium and vitamin D. The postnatal period was characterised by frequent infections of the genitourinary tract, and a bilateral pyelocaliectasis with vesicoureteral reflux was diagnosed. A chromosome analysis at 7 months revealed a de novo deletion (10)(p13). At the age of 6 years, hypocalcaemia persisted and parathyroid hormone levels were at the lower normal range. He suffered from frequent infections. A t age 10 he had a height of $126 \mathrm{~cm}$ (p50-75), a weight of $25 \mathrm{~kg}$ ( $p 90)$ and a head circumference of $51 \mathrm{~cm}$ ( p10-25). H e showed generalised muscular hypotonia, a spastic diplegia and mental retardation. U ntil age 6 , he showed autism, which was partially resolved at the age of $96 / 12$ years. He sat at 18 months, walked at 3 years, and was able to speak two words at the age of $104 / 12$ years.

Patient 3 The male patient HOV is the second child of healthy unrelated parents (mother 29 years old, father 27 years old). H e was born in the 36th week after an uncomplicated pregnancy with a weight of $2300 \mathrm{~g}$ (p10-25), a length of $45 \mathrm{~cm}$ (p10-25), and APGAR scores of 7 and 9 at 1 and $5 \mathrm{~min}$, respectively. Physical examination of the patient at birth revealed cryptoorchidism on the right side, hypospadia, two accessory nipples, muscular hypotonia, and facial dysmorphisms, including blepharophimosis and preauricular pits on the right side (Table 1). A chromosomal analysis was performed, and a de novo deletion (10)(p13) was diagnosed. Laboratory investigations revealed hypocalcaemia with a serum total calcium level of $1.5 \mathrm{mmol} / \mathrm{l}$ (normal range $2.5-2.8 \mathrm{mmol} / \mathrm{l}$ ) and an ionised calcium of $0.5 \mathrm{mmol} / \mathrm{l}$ (normal range $0.9-1.4 \mathrm{mmol} / \mathrm{l}$ ). Parathyroid hormone was in the lower normal range. The postnatal period was characterised by frequent genitourinary tract infections and muscular hypertonia. A reduced number of T-Iymphocytes was found. U Itrasound of heart and thymus, and electrocardiogram were normal. A t 4 10/12 years (Figure 1c) he had a length of $92 \mathrm{~cm}(<\mathrm{p} 3)$, a weight of $11.4 \mathrm{~kg}(<\mathrm{p} 3)$ and a head circumference of $47.5 \mathrm{~cm}(<p 3)$. At this age hypocalcaemia persisted. He had sensorineural hearing loss of moderate degree on the right side and sensorineural and conductive hearing loss on the left side. Thoracic scoliosis was present. He sat at 13 months, stood with support at 2 years, and began to walk at 4 10/12 years. $\mathrm{H}$ is psychomotoric development corresponded to a 9-10 month-old child.

Patient 4 The male patient R OB was the third child born to a healthy 24 year-old mother and 28 year-old father. The mother smoked heavily during pregnancy. The boy was born after an uncomplicated pregnancy in the 35th week of gestation with a weight of $2140 \mathrm{~g}$ (p10-25), a length of $42 \mathrm{~cm}(p 3-10)$ and a head circumference of $31 \mathrm{~cm}$ (p25-50). The child was hospitalised after birth for nine weeks for transient hypoglycaemia, hypokalaemia and hypocalcaemia. In the first eight months he was hospitalised twice for pneumonia and enteritis. At 9 months a right-sided herniotomy and orchidopexy was performed. R epeated electrocardiograms and echocardiograms revealed a low-grade valvular stenosis of the aorta. $\mathrm{H}$ is reaction to sound seemed present but reduced. Except for a predisposition to herpes labialis infections, there were no indications of immunological abnormalities. Cytogenetic analysis revealed a de novo deletion (10)(p12). D ata of phenotypic analysis at age 11 months are presented in Table 1. Ptosis of both eyes was corrected surgically. When seen last at the age of $96 / 12$ years (Figure $1 d$ ), he showed severe physical and mental retardation, and was unable to stand or walk.

Patient 5 The male patient KA N was born in O saka as the first child of a healthy 32 year-old Japanese mother and a 53 year-old Indian father. Two paternal half-brothers are healthy. He was born at term after an uncomplicated pregnancy with a weight of $2700 \mathrm{~g}$ (p3-10) and a length of $47 \mathrm{~cm}$ (p3-10). The child was hospitalised as a neonate for five weeks because of respiratory difficulties, and failure to thrive. D uring the first year of life he suffered from recurrent respiratory infections. A t 11 months the B - and T-cell counts were within the normal age-specific range. However, the T-cell subpopulations showed an inverse ratio of helper and suppressor T-cells, and we were unable to stimulate the T-cells with phytohaemagglutinin and concavalin A . IgG and IgM levels were increased (IgG $2063 \mathrm{mg} / 100 \mathrm{ml}$, normal range $350-1180 \mathrm{mg} / 100 \mathrm{ml}$; I gM $612 \mathrm{mg} / 100 \mathrm{ml}$, range $36-104 \mathrm{mg} / 100 \mathrm{ml}$ ), with a normal distribution of IgG subclasses, $X$-rays confirmed that the thymus was present. Laboratory investigation revealed hypocalcaemia $(1.72 \mathrm{mmol} / \mathrm{l}$; normal range 2.05-2.70 $\mathrm{mmol} / \mathrm{l})$. The parathyroid hormone level was very low $(0.08 \mathrm{ng} / \mathrm{ml}$, normal range $0.24-1.15 \mathrm{ng} / \mathrm{ml})$. Cytogenetic analysis revealed a de novo deletion (10) (p13). A t the age of 3 years (Table 1) his weight was $10.3 \mathrm{~kg}(<\mathrm{p3})$, his length was $87 \mathrm{~cm}$ (p3) and his head circumference was $47 \mathrm{~cm}$ (p3). A nephroureterectomy of the left kidney, an extirpation of the left testis and an orchidopexy on the right side was performed. The boy 
was severely retarded, but otherwise in good physical condition.

\section{Deletion analysis}

A microdeletion $22 q 11$ was excluded in all patients of this study by the demonstration of signals on both homologs with cosmid N25 (O ncor) corresponding to the locus D22S75, which maps within the DGSNCFS microdeletion region at $22 q 11$.

of the $1210 p$ deletions, eight were terminal and four were interstitial (Figure 2). A Il patients who were defined as having a terminal deletion were hemizygous for the cosmid CTBQ14.16 (D 10S33), which was the most distal locus tested (Table 2).

The largest deletions were found in patients $R O B$, TAT and KAN. The breakpoints in KAN, TAT and ROB map within the $2 \mathrm{cM}$ interval between D $10 \mathrm{~S} 548$ (deleted) and D10S211 (present), and the deletions encompass at least $46 \mathrm{cM}$ according to the Whitehead database. The second largest terminal deletion was found in $\mathrm{HOV}(38 \mathrm{cM})$. The breakpoints of the terminal deletions in patients MAJ, BIH and GM 6936 were mapped within a $4 \mathrm{cM}$ interval between D 10S585 and D 10S223. Fine mapping demonstrated that the breakpoints do not cluster (Table 2).

The smallest terminal deletion was found in patient LEM and encompasses 30 CM. Y A C 918 h11 (D 10S547) was hemizygous and YAC 773c3 (D 10S585) was dizygous in this patient. YAC $747 \mathrm{~h} 7$ overlaps with YACs $918 \mathrm{~h} 11$ and $773 \mathrm{c3}$, and was found to be dizygous in LEM , suggesting that the breakpoint maps within this YAC. However, we did not identify a weaker signal of this Y A C on the deleted chromosome 10 in comparison to the normal chromosome 10. B ecause no information about the size of YAC $747 \mathrm{~h} 7$ was available from the database, we performed pulsed field gel electrophoresis (PFGE) and determined a size of $1.4 \mathrm{M} \mathrm{bp.} \mathrm{PCR}$ analysis showed that the YAC $747 \mathrm{~h} 7$ includes the loci

Table 2 Loci and probes used for FISH analysis

\begin{tabular}{|c|c|c|c|c|c|c|c|c|c|c|c|c|c|c|}
\hline L ocus & $\begin{array}{l}\text { G enetic map } \\
\text { position (cM) }\end{array}$ & Probe & G M 3470 & AMS & MEG & MAR & LEM & G M 6936 & $\mathrm{BIH}$ & MAJ & HOV & ROB & TAT & KAN \\
\hline D 10S33 & $0-8$ & cTBQ 14. 16 & + & + & + & + & - & - & - & - & - & - & - & - \\
\hline D $10 S 552$ & 14 & $809 f 9$ & & + & & + & & & & & & & & - \\
\hline D 10S189 & 18 & $876 f 3$ & & + & + & - & $-*$ & - & - & -* & -* & & & \\
\hline D $10 S 226$ & 27 & $627 a 4$ & + & $t^{*}$ & & -* & & & - & -* & & & - & \\
\hline D $10 S 1720$ & 27 & PAC 12312 & & $t^{*}$ & + & & - & & & & $-*$ & & & \\
\hline W I-600 & & PAC 414017 & & & + & & - & & & & & & & \\
\hline D $10 S 547$ & 29 & 918h11 & + & & + & & - & & - & & & - & - & - \\
\hline WI-2389 & & PA C 204F 19 & & - & - & & - & & & & & & & \\
\hline D $10 S 585$ & 30 & PAC 323N 1 & + & - & - & & - & & & & & & & \\
\hline D $10 S 585$ & 30 & $773 c 3$ & + & $-*$ & - & & + & - & - & & -* & - & - & - \\
\hline D $10 S 1216$ & & $916 \mathrm{~d} 6$ & & $-*$ & - & & & - & & - & - & & & - \\
\hline D $10 S 1705$ & 33 & & $t^{*}$ & $-*$ & & & $t^{*}$ & & $t^{*}$ & -* & $-*$ & & & \\
\hline D 10S570 & 34 & $815 c 2$ & $(+)$ & & & & & & & -* & -* & & & \\
\hline D $10 S 223$ & 34 & $808 a 2$ & - & & - & & & + & $+/ t^{*}$ & + & & - & - & - \\
\hline D $10 S 191$ & 38 & $855 \mathrm{~d} 10$ & - & $-*$ & - & -* & $t^{*}$ & + & & $+/ t^{*}$ & $-1+*$ & $-/-*$ & - & \\
\hline D $10 S 548$ & 46 & $817 e 11$ & - & & & - & & & & & $+*$ & - & - & - \\
\hline D 10S203 & 47 & $696 f 5$ & & & - & & & + & & & & & - & - \\
\hline D $10 S 595$ & 47 & $764 \mathrm{gl}$ & - & $t^{*}$ & & - & & & & & & & & \\
\hline D $10 S 211$ & 48 & $807 \mathrm{~b} 3$ & & & & + & & & & & & + & + & + \\
\hline D 10S586 & 49 & $934 \mathrm{e} 11$ & - & & + & & & + & & & & + & & \\
\hline D 10S1747 & 49 & $805 \mathrm{e} 6$ & $(+)$ & & & & & & & & & & & \\
\hline D 10S572 & 52 & $875 b 4$ & + & & & & & + & & & & & + & \\
\hline D 10S197 & 53 & & & $t^{*}$ & & $t^{*}$ & & & & $t^{*}$ & & & & $t^{*}$ \\
\hline
\end{tabular}

The order of deletion patients from left to right in the table corresponds to their order from bottom to top in Figure 2. The order of loci and their map position is taken from the Whitehead Institute.

The map position of locus D $10 S 33$ was taken from the EUROGEM map [50]. In that study D 10S33 was mapped distally to D 10S32, which was given a map position of $8 \mathrm{cM}$.

+Presence of the locus/corresponding YAC on both chromosomes 10; $(+)$ weaker FISH signal of the YAC on the deleted chromosome 10; - absence of the locus/corresponding YAC on the deleted chromosome 10; *results of PCR analysis of polymorphic loci, which were informative in the patient or family.

The locus D 10S570 maps to the same recombination interval as D $10 S 223$ in the Généthon linkage map (M ay 1997). PCR analysis demonstrated that for D 10S570 only the YAC 815c2 was positive (overlapping YA C 916d6 and distal YAC 808a2 were negative). The finding that M A J with a terminal 10p deletion is hemizygous for D 105570 but dizygous for the Y A C 808a2, suggests that D $10 S 570$ maps distal to D $10 S 223$. 

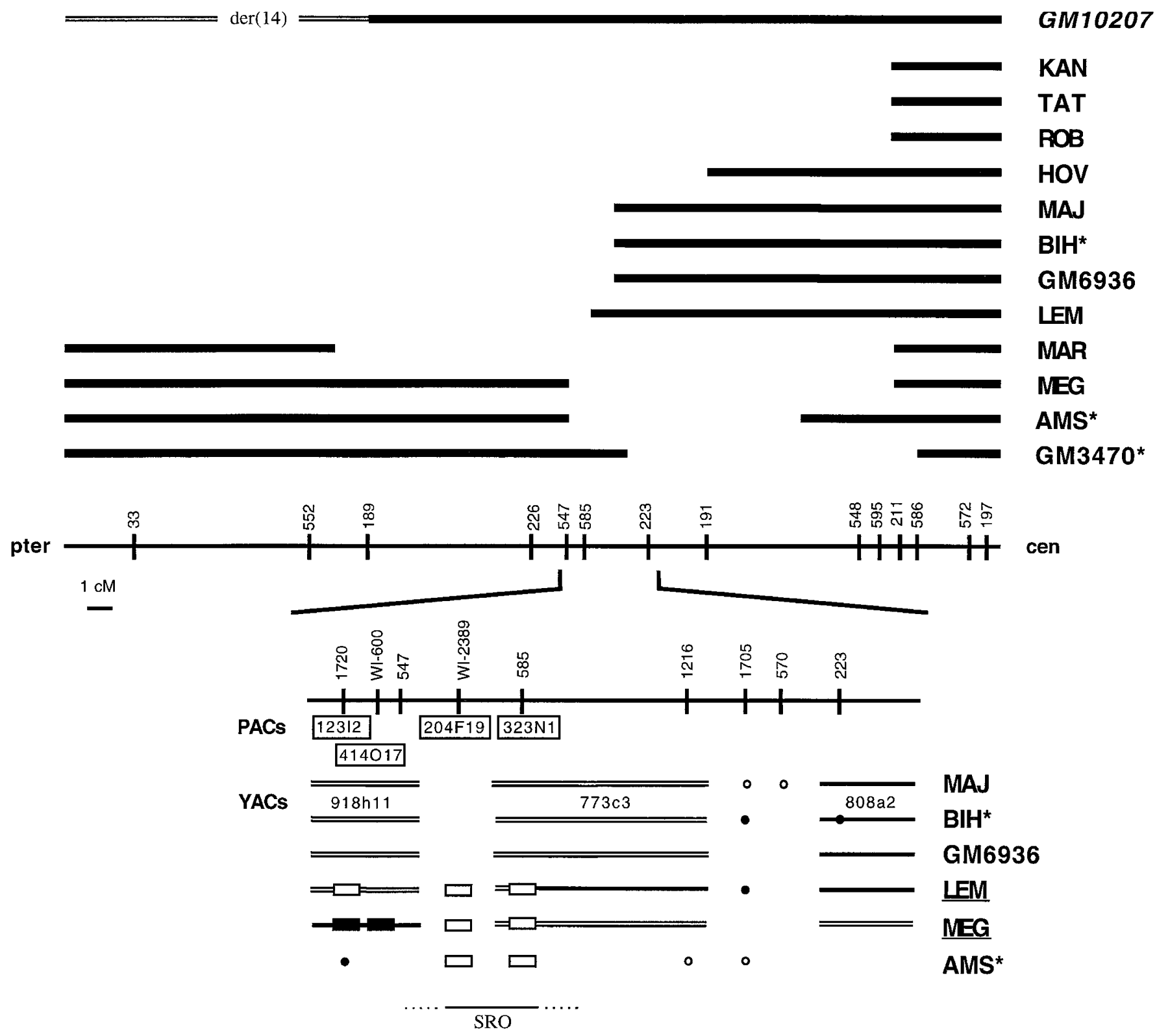

Figure 2 D el etion map of patients with chromosome 10 aberrations. Solid horizontal bars indicate regions not deleted in the patients. Patients with an asterisk do not show a typical D G S phenotype. G M 10207 has a reciprocal translocation (10p; 14q). The genetic map between markers D 10S33 and D 10S197 is drawn approximately to scale. A the bottom, the D G S2N CFS2 region is shown in detail. YACs are drawn as bars, PACs as boxes, and the results of microsatellite analyses as dots. O pen symbols represent the hemizygous (deleted) state; filled symbols represent the dizygous (not deleted) state. Underlined patients L E M and M E G define the proximal and distal boundaries of the DGS2NVCFS critical region (SRO, smallest region of overlap).

D 10 S547 and D 10S585, and carries a deletion. A ccording to the Whitehead database the YA C 747h7 does not contain the marker D 10S585. Further FISH analysis in patient LEM with several PAC clones demonstrated hemizygosity for the PAC 323N 1 (D 10S585). D 10S585 maps to the distal segment of the YAC $773 c 3$, for which LEM is dizygous. Thus, it can be concluded that the breakpoint in LEM maps within $773 c 3$.
The interstitial deletions are ordered in Figure 2 from distal to proximal deletion intervals. Patient MAR shows the most distal and largest interstitial deletion. The distal breakpoint maps within the $4 \mathrm{cM}$ interval between D10S552 and D 10S189 and the proximal breakpoint maps within the $1 \mathrm{cM}$ interval between the Ioci D 10S595 and D 10S211. Thus the deletion encompasses 29-32 cM . 
The interstitial deletion of patient MEG encompasses about $18 \mathrm{cM}$, and includes the loci from D $10 S 585$ distally to D $10 \mathrm{~S} 203$ proximally. The distal breakpoint maps between D10S547 (YAC 918h11 dizygous) and D $10 S 585$ (YAC 773c3 hemizygous). YAC 747h7, which overlaps with the YA C s $918 \mathrm{~h} 11$ and $773 \mathrm{c3}$ was dizygous in the patient, suggesting that the breakpoint maps within YAC 747h7. A s in patient LEM, we did not find a weaker signal of this YAC on the deleted chromosome 10 in comparison with the normal chromosome 10 to support this assumption. Further analysis with PAC clones demonstrated hemizygosity for the PA C 204F 19 (WI-2389) and dizygosity for the PA C 414017 (WI-600). Thus, the distal breakpoint of MEG maps between STS WI-600 (intact) and STS WI-2389 (deleted) within YAC747h7. The proximal breakpoint in MEG maps within the $1 \mathrm{cM}$ interval between D10S595 and D 10 S563.

The distal breakpoint in patient A M S maps between D $10 S 1720$ and WI-2389 and the proximal breakpoint maps between D 10S191 and D 10S595 giving a deletion size of $10-18 \mathrm{cM}$.

The most proximal deletion was found in G M 3470 . The distal breakpoint in this cell line was mapped by FISH analysis with the YAC $815 c 2$, which was isolated from the CEPH -M ega Y A C library, and corresponds to D 10S570. This YAC showed only a weak signal on the deleted chromosome 10 compared to the normal chromosome 10, and a signal at $5 q$ on both homologues. This suggests that the breakpoint in GM 3470 maps within the YAC $815 \mathrm{C} 2$ and demonstrates a chimera of this YAC. PCR analysis of the locus D 10S1705 showed heterozygosity in the patient. D10S1705 maps distal to Y A C 815c2 according to the database of the W hitehead Institute. These apparently contrasting results suggest a complex chimera of YAC $815 \mathrm{c} 2$. In addition to a chromosome $5 q$ sequence, the YAC contains two $10 p$ regions corresponding to WI-9659 and D10S570. W I-9659 maps proximally to D 10S1705, and is dizygous in GM3470, D $10 S 570$ maps distally to D $10 S 1705$ (according to the $G$ énéthon linkage map, $M$ arch 1996), and is hemizygous in GM 3470. A nother, rather unlikely, cause for the contrasting results would be a complex rearrangement in GM3470. The proximal breakpoint maps within the Y A C 805e6, which shows a weaker signal on the del(10p) chromosome compared with the normal chromosome. Therefore, the deletion of G M 3470 encompasses about $15 \mathrm{cM}$.

FISH analysis was also used to define the $10 p$ breakpoint interval of the translocation $(10 p ; 14 q)$ in patient GM 10207. We mapped the breakpoint within the $4 \mathrm{cM}$ interval between D $10 S 552$ and D 10 S189.

\section{Parental origin}

The parental origin of de novo deletions in patients AMS, LEM, HOV, ROB, and KAN were determined. Four terminal deletions were found to be of paternal ( $L E M, H O V, R O B, K A N$ ) and one of maternal (A MS) origin. The parental origin of the de novo deletion could not be determined in patients GM3470, MEG, MAR, GM 6936, BIH, and TAT because of a lack of parental $D N A$. The deletion in patient $M A J$ is due to a maternal pericentric inversion. ${ }^{15}$

\section{Discussion}

\section{Critical DGS2 Region}

In order to define a haploinsufficiency region for DGS on chromosome 10p, we performed molecular deletion analysis in 12 patients with partial monosomy 10p. Genotype-phenotype correlation studies are potentially complicated by cases derived from parental translocations or inversions in which both monosomy and trisomy of different chromosomal segments are present. To exclude interferences from such double segment aneuploidies, we concentrated on cases with monosomy 10p alone. The only exception is patient M A J, who carries a cytogenetically invisible trisomy of distal $10 q$, minimising the amount of the trisomic material. ${ }^{15}$ It is known from several studies that there is a wide variability in the phenotypic features of patients with deletions or duplications of the same chromosomal region, such as partial monosomy $4 p$ in patients with Wolf syndrome, and partial monosomy $5 p$ in cri du chat syndrome. ${ }^{45}$ For this reason, the presence of a particular trait in a patient carries more weight than its absence. Nine patients are informative for the determination of an haploinsufficiency region for DGS/V CFS, since they show features of DGS (LEM, MAJ, HOV, ROB, TAT, KAN) or VCFS (MEG, MAR).

The smallest region of overlap (SRO) is defined by the terminal deletion in patient LEM and the interstitial deletion of patient MEG (Figure 2). Patient LEM shows clinical signs of immunodeficiency and has persistent hypoparathyroidism, but no heart defect. $\mathrm{H}$ ypoparathyroidism alone is known from $22 q 11$ deletions, $^{12}$ and therefore we conclude that this patient can 
be used for the determination of the critical region for DGS2. Patient MEG shows typical features of the VCFS including ventricular septal defect, cleft palate and T-cell deficiency. ${ }^{31}$

The only YAC which was found to be dizygous in both patients LEM and MEG (747h7) carries a deletion. For the distal YA C 918h11 (D 10S547) patient LEM is hemizygous and patient MEG is dizygous. For the proximal YAC 773c3 (D 10S585), the situation is reversed. Thus the boundaries of the SRO are defined by these two YACS, which both overlap with YAC 747h7. For further definition of the SRO, FISH was performed with PACs corresponding to loci adjacent and between these YACS. Both LEM and MEG were hemizygous for the PACs 323N 1 and 204F 19 corresponding to D $10 S 585$ and $\mathrm{WI}-2389$, respectively. A II patients of the present study with features of DGS or V CFS are hemizygous for these two PACS, which define the minimal SRO in the DGS/VCFS patients of this study. Our results refine the DGS2 deletion interval defined and estimated to encompass about $2 \mathrm{Mb}$ by $\mathrm{D}$ aw et $\mathrm{al}^{36}$ although the exact breakpoints have yet to be determined. The breakpoint in patient LEM narrows the interval by approximately $1 \mathrm{Mb}$. LEM is dizygous for the YAC 773c3, while the patients analysed by D aw et al are hemizygous. A ccording to the genetic map the critical DGS2 region is approximately $1 \mathrm{cM}$, which is the distance given between loci D $10 S 585$ and D 105547. So far no genes have been mapped to the D G S2 region. However, due to the possibility of position effects, which are well known for several haploinsufficiency genes in humans, ${ }^{44}$ a candidate region of at least $500 \mathrm{~kb}$ around the SRO has to be considered. Genes in the vicinity of the 10p translocation breakpoint associated with cleft lip and ventricular septum defect (VSD) are unlikely to be involved in DGS2, because the breakpoint interval maps about $12 \mathrm{cM}$ distal to the DGS2 region.

In general, there is a chance that the pathogenesis of D G S2/V CFS2 might be more complex and several loci separated by larger intervals might contribute to the D GS phenotype. The possibility of a haploinsufficiency locus causing congenital hypoparathyroidism alone without T-cell deficiency and heart defect has been stressed by molecular analysis of two terminal deletion patients with a breakpoint just distal to the critical DGS2 region. ${ }^{45}$ Interestingly, patient $M E G$, who is dizygous for the region deleted in these two patients did not show hypoparathyroidism, while all DGS patients with a terminal deletion of our study did.

\section{Phenotypic Spectrum of DGS2 versus DGS1}

Regarding the phenotypic expression of the DGS spectrum in patients with partial monosomy 10p, there are both similarities and differences to DGS1. Both partial monosomy 10p and partial monosomy 22q11 are associated with a variable expression of the $D G S$, with a significant proportion of patients presenting only a subset of the DGS features. The VCFS belongs to the phenotypic spectrum of both partial monosomy $10 p$ and partial monosomy 22q11. Patients A MS and $\mathrm{BIH}$ of this study have no features of the DGS/VCFS spectrum, but they are hemizygous for the critical DGS2/V CFS2 region. This provides evidence for a reduced penetrance of D G S2/V CF S2, which is also well known for D GS1/V CFS1.

Renal abnormalities have been found in $36 \%$ of patients with partial monosomy $22 q 11^{46}$ and in six of the nine DGS2/NCFS2 patients of this study. Thus, abnormalities of the urinary tract might be more common in D GS2/V CFS2 than in D GS1/V CFS1. H eart defects in monosomy 10p involve tetralogy of Fallot, atrial septal defect, ventricular septal defect, aortic valve stenosis and pulmonary stenosis, and thus appear to be more heterogeneous than in patients with partial monosomy 22q11. While the common deletion region in DGS1 and VCFS1 encompasses about $2 \mathrm{M}$ bp, with identical breakpoints in about $95 \%$ of patients, the size of the deletions in the patients of this study varies from about 20 to $40 \mathrm{M} \mathrm{bp}$. Fine mapping gave no evidence for a clustering of breakpoints. Thus, regarding renal abnormalities and heart defects, the differences observed between DGS1/VCFS1 and DGS2/VCFS2 are compatible with a variable set of deleted genes in partial monosomy 10p.

The parental origin of the deletion is known in 6/12 deletion patients investigated. There is no evidence for imprinting effects. Both patients MAJ and AM S have deletions of maternal origin, and present with all typical D GS features or no D G S feature, respectively. The four deletions of paternal origin (in patients LEM, HOV, $R O B, K A N$ ) were associated with a variable spectrum of $D G S$ features.

\section{Tentative Mapping of other 10p Disease Loci}

The deletions described in this study range from at least $10 \mathrm{cM}$ in patient A MS to almost $50 \mathrm{cM}$ in patients TAT and KAN. The deletion patients present with several phenotypic features, which are not part of the DGS/ VCFS spectrum. This enables the tentative mapping of 
disease loci other than DGS to the short arm of chromosome 10.

Ptosis is not very common in chromosomal aneuploidy syndromes and was observed in six patients of this study (MAR, MA J, HOV, ROB, TAT, KAN). The molecular data of these patients suggest that gene(s) on $10 p$ responsible for this phenotype map between D 10S552, which flanks the interstitial deletion of M A R distally, and D 10S223, which flanks the terminal deletion of MAJ.

$\mathrm{H}$ earing loss was found in three of eight patients in this study (BIH, M A J, HOV) and has been described in at least four other patients with partial monosomy 10 . $^{30,34,47,48}$ Because several patients have been reported at an age before hearing loss might be obvious, and because in other reports no information on this feature is given, we argue that hearing loss might be more common in partial monosomy 10p than reported to date. The deletion breakpoints of patients $\mathrm{BIH}, \mathrm{MAJ}$ and HOV suggest that gene(s) involved in hearing loss map distal to D 10S1705, for which BIH with a terminal deletion is dizygous. More investigations are necessary to determine the type of hearing loss in the affected patients.

Probes from the refined deletion interval can now be used to screen for 10p microdeletions in patients where monosomy $22 q 11$ has been excluded. Criteria for the characterisation of candidate genes from the DGS2 deletion region include spatial and temporal expression patterns, sequence homologies to known developmental domains including DGS1 candidates and, last but not least, knock-out mice experiments.

\section{Acknowledgements}

This study was supported by Deutsche Forschungsgemeinschaft and Friedrich-B aur-Stiftung. We thank C. Schlichtinger for cytogenetic assistance, the late A . Lipson for providing the cell line from patient MEG, and S. D aw and P. Scambler for sharing data prior to publication.

\section{References}

$1 \mathrm{~L}$ ammer EJ, O pitz JM: The DiGeorge anomaly as a developmental field defect. A m J M ed Genet 1986; Suppl 2: 113-127.

2 Wilson DI, Burn J, Scambler P, G oodship J: DiG eorge syndrome: Part of CATCH 22. J Med Genet 1993; 30: 852-856.
3 D riscoll DA, Salvin J, Sellinger B et al: Prevalence of 22q11 microdeletions in DiGeorge and velocardiofacial syndromes: implications for genetic counselling and prenatal diagnosis. J M ed G enet 1993; 30: 813-817.

4 Carey A H, Kelly D, Halford S et al: Molecular genetic study of the frequency of monosomy 22q11 in DiGeorge syndrome. A m J H um G enet 1992; 51: 964-970.

5 Demczuk S, L évy A, A ubry $M$ et al: $E$ xcess of deletions of maternal origin in the DiG eorge/Velo-cardio-facial syndromes. A study of 22 new patients and review of the literature. H um G enet 1995; 96: 9-13.

6 M otzkin B, M arion R, G oldberg R, Shprintzen R, Saenger $P$ : Variable phenotypes in velocardiofacial syndrome with chromosomal deletion. J Paediatr 1993; 123: 406-410.

7 Scambler PJ: Deletions of human chromosome 22 and associated birth defects. Curr O p G enet D evelop 1993; 3: 432-437.

8 D emczuk S, Gilles T, A urias A : I solation of a novel gene from the DiG eorge syndrome critical region with homology to Drosophila gdl and to human LSAMC1 genes. Hum Mol G enet 1996; 5: 633-638.

9 A ubry M, D emczuk S, D esmaze $C$ et al: I solation of a zink finger gene consistently deleted in $\mathrm{DiG}$ eorge syndrome. H um Mol G enet 1993; 2: 1583-1587.

10 Kurahashi H, A kagi K, Inazawa J et al: Isolation and characterization of a novel gene deleted in DiGeorge syndrome. Hum M ol G enet 1995; 4: 541-549.

$11 \mathrm{H}$ alford S, Wilson DI, Daw SCM et al: I solation of a gene expressed during early embryogenesis from the region of 22 q11 commonly deleted in DiG eorge syndrome. H um M ol G enet 1993; 2: 1577-1582.

12 Pizzuti A, Novelli G, Ratti A et al: UFD 1 , a developmental expressed ubiquination gene, is deleted in CATCH 22 syndrome. H um M ol G enet 1997; 6: 259-265.

13 Fukushima $Y$, Ohashi $H$, Wakui $K$ et al: DiGeorge syndrome with del(4)(q21.3q25): Possibility of the fourth chromosome region responsible for $\mathrm{DiG}$ eorge syndrome. A m J H um G enet 1992; 51 (Suppl): A 80.

14 Taylor M J, J osifek K : M ultiple cogenital anomalies, thymic dysplasia, severe congenital heart disease, and oligosyndactyly with a deletion of the short arm of chromosome 5. A m J M ed G enet 1981; 9: 5-11.

15 Schuffenhauer S, Seidel H, O echsler H et al: DiGeorge syndrome and partial monosomy 10p: case report and review. A nn G énét 1995; 38: 162-167.

16 G reenberg F, E Ider FFB, $H$ affner $P$, N orthrup $H$, L edbetter $\mathrm{DH}$ : Cytogenetic findings in a prospective series of patients with DiG eorge anomaly. A m J H um G enet 1988; 43: 605-611.

17 Siu VM, Li M-D, Teshima IE: De novo interstitial $2 q$ deletion in a child with features of DiGeorge syndrome. A m J H um G enet 1996; 59: A 133.

18 Lindgren V, Rosinsky $B$, Chin J, Berry-K ravis $E$ : Two patients with overlapping de novo duplications of the long arm of chromosome 9 , including one case with DiG eorge sequence. A m J Med G enet 1994; 49: 67-73.

19 Schinzel A : Catalogue of U nbalanced Chromosome A berrations in M an. Walter De Gruyter, Berlin: 1984.

20 Van Essen AJ, Schoots CJF, Van Lingen RA, Mourits MJE, Tuerlings J HA M , L eegte B: I sochromosome 18q in a girl with holoprosencephaly, DiGeorge anomaly, and streak ovaries. A m J M ed G enet 1993; 47: 85-88. 
21 Vanden Berghe $H$, Van Eggen $M$, Fryns J $P$, Tanghe $W$ : Partial trisomy 1. H um G enet 1973; 19: 225-230.

22 Townes PI, White M R : Inherited partial trisomy 8q. A m J D is Child 1978; 132: 498-501.

23 Wullich B, H enn W, G roterath E, E rmis A, Fuchs S, Z ankI $M$ : M osaic tetraploidy in a liveborn infant with features of the DiG eorge anomaly. Clin G enet 1991; 40: 353-357.

24 Gencik A, Brönniman U, Tobler R, A uf Der Maur P: Partial monosomy of chromosome 10 short arms. J Med G enet 1993; 20: 107-111.

25 Hervé J, Warnet J F, Jeaneau-B ellego E, Portnoi MF, Taillemitte J L, Hervé F: M onosomie partielle du bra court d'un chromosome 10, associée à un syndrome de R ieger et à un déficit immunitaire partiel, type DiGeorge. Ann Pédiat 1984; 31: 77-80.

26 G reenberg $F$, Valdes $C$, R osenblatt $H M, K$ irkland $J L$, Ledbetter $D$ : Hypoparathyroidism and $T$ cell immune defect in a patient with $10 p$ deletion syndrome. J Pediat 1986; 109: 489-492.

27 M onaco G, Pignata C, R ossi E, M ascarello O, Cocozza S, Ciccimarra F: DiGeorge anomaly associated with $10 p$ deletion. A m J M ed G enet 1991; 39: 215-216.

28 Koenig $R$, K essel $E$, Schoenberger W: Partial monosomy 10p syndrome. A nn G énét 1985; 28: 173-176.

29 Goodship J, Lynch S, Brown J, Cross I, Milligan D: Comparison of facial features of DiGeorge syndrome (dgs) due to deletion 10p13-10pter with dgs due to $22 q 11$ deletion. A m J H um G enet 1994; 55 (Suppl): A 105.

30 Obregon M G, M ingarelli R, G iannotti A, Di Comite A, Spedicato FS, Dallapicolla B: Partial deletion 10p syndrome. A nn G énét 1992; 35: 101-104.

31 Lipson A, Fagan K, Colley A et al. Velo-cardio-facial and partial DiGeorge phenotype in a child with interstitial deletion at 10p13 - implications for cytogenetic and molecular biology. A m J M ed Genet 1996; 65: 304-308.

32 B ridgman $G, B$ utler $L J$ : A child trisomic for the distal part of chromosome 14q. Arch Dis Childhood 1980; 55: 474-477.

33 Fisher E, Scambler P: H uman haploinsufficiency - one for sorrow, two for joy. Nat G enet 1994; 7: 5-7.

34 Shapira M, B orochowitz Z, Bar-EI H, Dar H, Etzioni A, L orber A : Deletion of the short arm of chromosome 10 (10p13): report of a patient and review. A m J M ed G enet 1994; 52: 34-38.

35 Cowchock S: A pparently balanced chromosome translocations and midline defects. A m J M ed G enet 1989; 33: 424.

36 D aw SC M, Taylor C, K raman $M$ et al: A common region of $10 p$ deleted in $\mathrm{DiG}$ eorge and Velocardiofacial syndromes. N at G enet 1996; 13: 458-460.
37 Gyapay G, M orisette J, Vignal A et al: The 1993-1994 $\mathrm{G}$ énéthon human genetic linkage map. $\mathrm{N}$ at $\mathrm{G}$ enet 1994; 7: 246-339.

38 M eitinger T, B oyd $Y, A$ nand $R$, Craig IW: Mapping of $X$ p21 translocation breakpoints in and around the DMD gene by pulsed field electrophoresis. Genomics 1988; 3: 315-322.

39 Ioannou PA, A memiya CT, Garnes J et al: A new bacteriophage $P 1$-derived vector for propagation of large human DNA fragments. Nat G enet 1995; 6: 84-89.

40 Dip C, Faure S, Fizames $C$ et al: A comprehensive genetic map of the human genome based on 5,264 microsatellites. Nature 1996; 380: 152-154.

41 Lichter $\mathrm{P}, \mathrm{Cremer} \mathrm{T}, \mathrm{B}$ orden J, M anuelidis L, Ward D C: Delineation of individual human chromosomes in metaphase and interphase cells by in situ suppression hybridisation using recombinant DNA libraries. $\mathrm{Hum}$ Genet 1988; 80: 224-234.

42 Lichter T, Tang C-J, Call $\mathrm{K}$ et al: $\mathrm{H}$ igh-resolution mapping of human chromosome 11 by in situ hybridisation with cosmid clones. Science 1990; 247: 64-68.

43 Korenberg JR: Towards a molecular understanding of Down syndrome. In: E pstein C (ed). The phenotypic mapping of D own syndrome and other aneuploid conditions Wiley-Liss: N ew York, 1994, 87-116.

44 M ilot $E$, Fraser $P, G$ rosveld $F$ : Position effects and genetic disease. TIG 1996; 12: 123-126.

45 M eitinger T, Scharfe C, Call K, M oschonas N : R eport on the second international chromosome 10 mapping 1997. Cytogenet Cell G enet; 78: 183-196.

46 Ryan A, Goodship JA, Wilson DI et al. Spectrum of clinical features associated with interstitial chromosome 22q11 deletions: A European collaborative study. J Med Genet 1997; 34: 798-804.

$47 \mathrm{H}$ on E, Chapmann C, Gunn T: Family with partial monosomy 10p and trisomy 10p. A m J M ed G enet 1995; 56: 136-140.

48 K inoshita Y, Tanaka Y, Yasuhara A, M atsuzaki S, Kuriki $\mathrm{H}$, Kobayashi $\mathrm{Y}$ : A case of deletion of the short arm of chromosome 10 with severe hearing loss and brainsteam dysfunction. A m J Perinat 1992; 9: 229-301.

49 Hudson TJ et al: A n STS-based map of the human genome. Science 1995; 270: 1945-1954.

50 Kapsetaki $M$, Kokkinaki $M$, A ngelicheva $D$ et al: The Eurogem map of human chromosome 10. Eur J Hum G enet 1994; 2: 222-223. 